\title{
Detection and Identification of Phytoplasmas in the 16SrIV-A, -B, and -D Subgroups in Palms in Tabasco, Mexico
}

\author{
Eder Ramos Hernández, ${ }^{1}$ Julia M. Lesher Gordillo, ${ }^{2}$ Carlos Oropeza Salín, ${ }^{3}$ Carlos F. Ortiz García, ${ }^{4, \dagger}$ Miguel A. Magaña Alejandro, ${ }^{2}$ \\ Saúl Sánchez Soto, ${ }^{4}$ and Yesenia García Estrada ${ }^{4}$ \\ ${ }^{1}$ Instituto Nacional de Investigaciones Forestales, Agrícolas y Pecuarias, Campo Experimental Huimanguillo, 86400, Huiman- \\ guillo, Tabasco, México \\ 2 Universidad Juárez Autónoma de Tabasco, División Académica de Ciencias Biológicas, 86150, Villahermosa, Tabasco, México \\ ${ }^{3}$ Centro de Investigación Científica de Yucatán A.C., 97205, Chuburná de Hidalgo, Mérida, Yucatán, México \\ ${ }^{4}$ Colegio de Postgraduados, 86500, Cárdenas, Tabasco, México
}

\begin{abstract}
The 16SrIV-A phytoplasmas are associated with the devastating disease lethal yellowing (LY) of palms. In Tabasco (Mexico), the death of Cocos nucifera, Adonidia merrillii, and Attalea butyracea palms have been suspected to be associated with LY based on symptomatology. Samples from the trunk of both symptomatic and nonsymptomatic palms were collected in three different environments: two species of palms within a rural zone and the other within an urban zone. DNA was extracted to perform a nested PCR with phytoplasma primers P1/P7-LY16SF/R16R2. A 1,345-bp fragment was amplified from the DNA extracted from each of the 29 LY-symptomatic palms sampled. Phytoplasma identification was
\end{abstract}

Abstract

achieved by amplicon sequencing and virtual restriction fragment length polymorphism analyses. Three $16 \mathrm{SrIV}$ phytoplasma subgroups were detected: 16SrIV-A in C. nucifera, 16SrIV-B in A. merrillii, and 16SrIV$\mathrm{D}$ in $C$. nucifera, A. merrillii, and A. butyracea. Phylogenetic analysis showed also that the three phytoplasma strains found in the palm species clustered with phytoplasmas reported in the literature in the three subgroups identified. This is the first report of phytoplasmas associated with these palm species in Tabasco.

Keywords: $16 \mathrm{SrIV}$ phytoplasmas, RFLP, pathosystem, host plants
Phytoplasma diseases affect approximately 1,000 plant species belonging to 98 families (Gasparich 2010) and are distributed worldwide in 85 countries (Lee et al. 2000), although some of them may be limited to one continent or one specific region (Lee et al. 1998a). Phytoplasma diseases cause important economic losses to many crops (Bertaccini et al. 2014). These bacteria lack cell walls, colonize the plant phloem tissues, and are transmitted by insect vectors, mainly leaf-hoppers, plant-hoppers, and psyllids (Bertaccini 2007).

The use of the polymerase chain reaction (PCR) and sequencing of the corresponding amplicons generated from the ribosomal RNA (rRNA) gene have allowed the identification and comparison of phytoplasma strains with techniques such as restriction fragment length polymorphism (RFLP) and phylogenetic analysis (Gundersen and Lee 1996; Lee et al. 1998b; Santos-Cervantes et al. 2008; Schneider et al. 1993; Wei et al. 2007). The interactive $i$ PhyClassifier tool (https://plantpathology.ba.ars.usda.gov/cgi-bin/ resource/iphyclassifier.cgi) performs a similarity analysis based on the sequence of the R16F2n/R2 fragment from the phytoplasma 16S rRNA gene (Zhao et al. 2013). This tool is used to do the preliminary classification of phytoplasmas at the group/subgroup level and/or to allocate them in 'Candidatus Phytoplasma' species (Nejat et al. 2013; Zhao et al. 2009a, 2013).

${ }^{\dagger}$ Corresponding author: C. F. Ortiz García; cfortiz@colpos.mx

Funding: The authors thank the Colegio de Postgraduados (COLPOS) for providing the infrastructure needed to carry out a part of this research. The European Union provided funds under the Horizon 2020 project: Insect borne prokaryote-associated diseases in tropical and subtropical perennial crops (TROPICSAFE: Grant Agreement No. 727459).

The author(s) declare no conflict of interest.

Accepted for publication 14 April 2020.

(C) 2020 The American Phytopathological Society
In the Americas, the devastating lethal yellowing (LY) disease in coconut (Cocos nucifera L.) is mainly associated with the presence of phytoplasmas belonging to the 16SrIV-A group (Harrison et al. 2002) and is transmitted by the American palm cixiid, Haplaxius crudus (Van Duzee) (Howard et al. 1983), which is the only described vector of LY in the western hemisphere. The phytoplasmas associated with LY and LY-type diseases in palms in the Americas have been classified into different subgroups in the 16SrIV group (Fig. 1) (Ntushelo et al. 2013; Vázquez-Euán et al. 2011). Subgroups include (i) 16SrIV-A, detected in the majority of palms that have been killed by LY; (ii) 16SrIV-B (Tymon et al. 1998); (iii) 16SrIV-D (Bahder et al. 2018a, 2018b; Cordova et al. 2017; Harrison et al. 2008; Rodrigues et al. 2010) (the phytoplasma disease associated with $16 \mathrm{SrIV}-\mathrm{D}$, currently termed lethal bronzing disease, is synonymous with Texas phoenix palm decline [TPPD]) (Bahder et al. 2018b); (iv) 16SrIV-E (Martinez et al. 2008); and (v) 16SrIV-F (Harrison et al. 2008). 16SrIV-C has been detected only in Africa and is known as Tanzanian coconut lethal decline.

More recently, phytoplasmas of other ribosomal groups have been identified in Arecaceae in other parts of the world: 'Candidatus Phytoplasma asteris' (16SrI), a phytoplasma that is also reported in oil palm in Colombia (Alvarez et al. 2014); ' $C a$. P. oryzae' (16SrXI) in India (Manimekalai et al. 2014); ' $\mathrm{Ca}$. P. cynodontis' (16SrXIV) (Nejat et al. 2009), 'Ca. P. malaysianum' (16SrXXXII) (Nejat et al. 2013), and ' $\mathrm{Ca}$. P. wodyetiae' in Malaysia (Naderali et al. 2017); ' Ca. P. palmicola' (16SrXXII) in Africa (Harrison et al. 2014); and ' $\mathrm{Ca}$. P. noviguineense' in Papua New Guinea (Miyazaki et al. 2018).

In an urban landscape in Yucatán, Mexico, where C. nucifera, Sabal mexicana Martius, Thrinax radiata Lodd. ex Schult. \& Schult. f., and Pseudophoenix sargentii $\mathrm{H}$. Wendl. ex Sarg. coexist, two phytoplasma subgroups,16SrIV-A and 16SrIV-D, have been found (Vázquez-Euán et al. 2011). In addition, these authors found that in a single palm species ( $S$. mexicana or $T$. radiata), both phytoplasma subgroups can be found, although never within a single individual palm. 
In Tabasco, another region of Mexico, plants of different palm species, including C. nucifera, Adonidia merrillii (Becc.) Becc., and Attalea butyracea (Mutis ex L.f.) Wess. Boer, were found showing LY-type symptoms. This study reports the analyses carried out in these palms to determine if the observed syndromes are associated with phytoplasmas and classify the detected phytoplasmas.

\section{Materials and Methods}

Palm sampling. Samples were collected from both symptomatic and asymptomatic $C$. nucifera, A. merrillii, and A. butyracea. Symptoms included fruit drop, necrotic inflorescence, and yellowing of low and intermediate leaves. Samples were collected from palms in different environments used for various purposes (large-scale commercial agriculture, family farming, ornamental), in Tabasco State (Table 1). C. nucifera samples were collected from rural communities in Pailebot, Cárdenas, a site with monoculture, and family gardens in Miahuatlán, Cunduacán. Additionally, A. merrillii palms from urban environments were sampled from the gardens of the Academic Division of Biological Sciences, Juarez Autonomous University of Tabasco, and the Cárdenas center housing unit. A. butyracea samples were collected in grassland areas of Miahuatlán, Cunduacán.

DNA extraction. A total of 42 trunk-boring samples (3 to $6 \mathrm{~g}$ ) were collected in 2017 from palms using a portable drill. Of each sample, $1 \mathrm{~g}$ was ground to a fine powder by placing it in liquid nitrogen and using a sterile mortar and pestle. Nucleic acid was extracted from the powdered tissue according to the method of Doyle and Doyle (1990). Aliquots from each final preparation were suspended

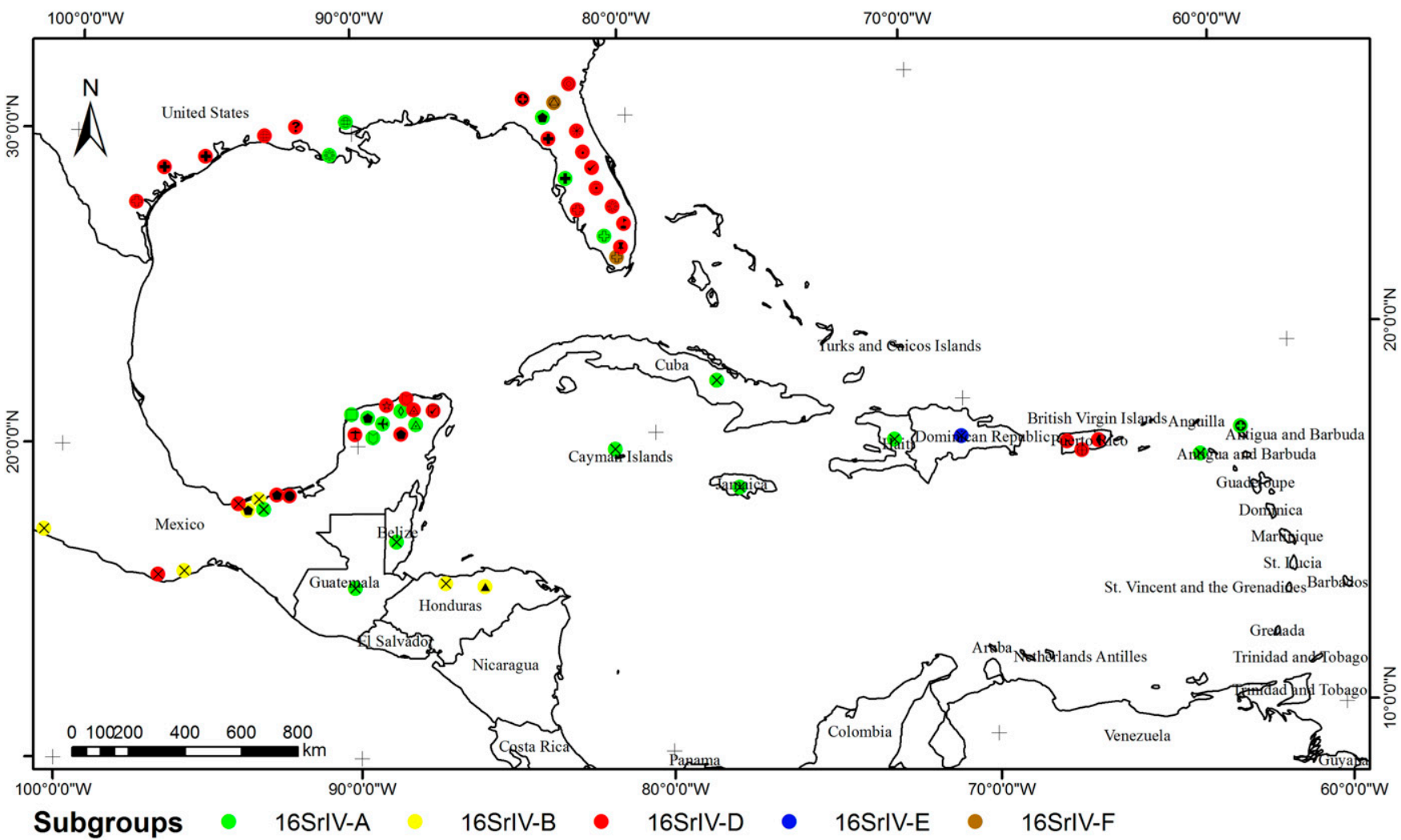

\begin{tabular}{|c|c|c|c|c|c|c|c|c|c|}
\hline$\Delta$ & Acromia aculeata & $\odot$ & Butiagrus nabonnandii & + & Phoenix canariensis & * & Phoenix sylvestris $\mathrm{x}$ dactylifera & () & Sabal palmetto \\
\hline$\square$ & Acromia mexicana & मे & Carludovica palmata & 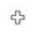 & Phoenix dactylifera & $\nabla$ & Pritchardia pacifica & $\oplus$ & Syagrus romanozoffiana \\
\hline - & Adonidia merrillii & ค & Carpentaria acuminata & $x$ & Phoenix reclinata & $t$ & Pseudophoenix sargentii & $\theta$ & Thrinax radiata \\
\hline$\bullet$ & Attalea butyracea & - & Caryota mitis & $:$ & Phoenix roebelenii & + & Roystonea regia & $\oplus$ & Trachycarpus furtunei \\
\hline ? & Bismarckia nobilis & $\diamond$ & Coccothrinax readii & s & Phoenix sylvestris & $\oplus$ & Roystonea sp. & $\otimes$ & Washingtonia robusta \\
\hline$\odot$ & Butia odorata $\times$ S. romanozoffiana & $x$ & Cocos nucifera & $\checkmark$ & Phoenix sylvestris $x$ canariensis & $\Delta$ & Sabal mexicana & & \\
\hline
\end{tabular}

Fig. 1. Distribution map of phytoplasmas in the 16SrIV group associated with lethal yellowing diseases in the palms of North and Central America and the Caribbean Islands.

Table 1. Ribosomal subgroups of 16SrIV phytoplasmas identified in symptomatic plants with lethal yellowing listed by agricultural activities, palm species, environment, and sampling sites within Tabasco State (Mexico)

\begin{tabular}{llcllc}
\hline Sampling site $^{\text {a }}$ & Environment/use & Symptomatic/sampled & Palm species & Density/culture & Phytoplasma identified \\
\hline Pailebot, Cárdenas & Rural/agricultural & $7: 11$ & Cocos nucifera & High/monoculture & 16 SrIV-A \\
Miahuatlán, Cunduacán & Rural/farming & $11: 16$ & Attalea butyracea & Low/polyculture & 16 SrIV-D \\
& & & C. nucifera & & 16 SrIV-D \\
& & C. nucifera & & 16 SrIV-A \\
& & Adonidia merrillii & & 16 SrIV-D \\
Center-DACBiol & Urban/ornamental & $8: 11$ & A. merrillii & Low/monoculture & 16 SrIV-B \\
Cárdenas housing unit & Urban/ornamental & $3: 4$ & A. merrillii & Low/monoculture & 16 SrIV-D \\
\hline
\end{tabular}

\footnotetext{
${ }^{a}$ DACBiol $=$ Academic Division of Biological Sciences, Juarez Autonomous University of Tabasco.
} 
in Tris-EDTA (TE) buffer (10 mM Tris, 1 mM EDTA, pH 8) and subsequently visualized in $1 \%$ agarose gels in TAE buffer (40 mM Trisacetate, $1 \mathrm{mM}$ EDTA).

Nested PCR. The employed protocol was according to Harrison et al. (2002a). Each DNA sample was diluted 1:10 with sterile deionized water, and subsequently $5 \mu \mathrm{l}$ of each dilution was used as the template for PCR amplification, including universal rRNA gene primers P1 (Deng and Hiruki 1991) and P7 (Schneider et al. 1995) for initial amplification $(1,800 \mathrm{bp})$. The product of the reaction was diluted 1:20 or 1:40 with sterile deionized water, and $5 \mu l$ of each dilution was then reamplified (1,345 bp) using primers LY16SF (Harrison et al. 2002a) and R16R2 (Lee et al. 1993). PCR amplifications were performed with a C1000 Thermal Cycler (Bio-Rad, Hercules, CA) using $1 \mathrm{U}$ of the Mango Taq DNA polymerase (Bioline, London, U.K.) in a $25-\mu l$ volume that contained $2 \mu$ lof dNTPs $(1.25 \mathrm{mM}), 5 \mu \mathrm{l}$ of $10 \times$ PCR buffer, $5 \mathrm{U}$ of Taq polymerase, and $2 \mu l$ of each primer $(25 \mathrm{ng} / \mu \mathrm{l})$. The reaction was performed with an initial 2-min cycle at $94^{\circ} \mathrm{C}$, followed by 35 cycles of $1 \mathrm{~min}$ at $94^{\circ} \mathrm{C}$, annealing for $50 \mathrm{~s}$ at $54^{\circ} \mathrm{C}\left(60^{\circ} \mathrm{C}\right.$ for LY16SF/R16R2), and extension for $80 \mathrm{~s}$ at $72^{\circ} \mathrm{C}$. Reactions were terminated by a 10 -min extension step at $72{ }^{\circ} \mathrm{C}$ and cooled to $4^{\circ} \mathrm{C}$. The PCR products were analyzed by electrophoresis with a $1 \%$ agarose gel stained with ethidium bromide and visualized by using a UV transilluminator Molecular Image Gel Doc XR System (Bio-Rad). Negative controls were DNA extracted from nonsymptomatic plants and sterile water. Coconut palm DNA (GenBank no. GU473590) previously identified as infected by LY was used as a positive control (Vázquez-Euán et al. 2011).

PCR product purification and sequencing. PCR amplicons from the LY16SF/R16R2 primers were purified in columns of the QIAquick Gel Extraction kit (cat. no. 28706; Qiagen, Hilden, Germany) according to the manufacturer's instructions. All purified products were quantified in a nanodrop spectrophotometer (JenwayGenova Nano, Stone, U.K.). The sequencing was performed with the 3500xl genetic analyzer (Applied Biosystems, Foster City, CA) at the Biotechnology Institute of the National Autonomous University of Mexico in both directions with primers used for the amplification plus the 503F primer (Harrison et al. 1999).
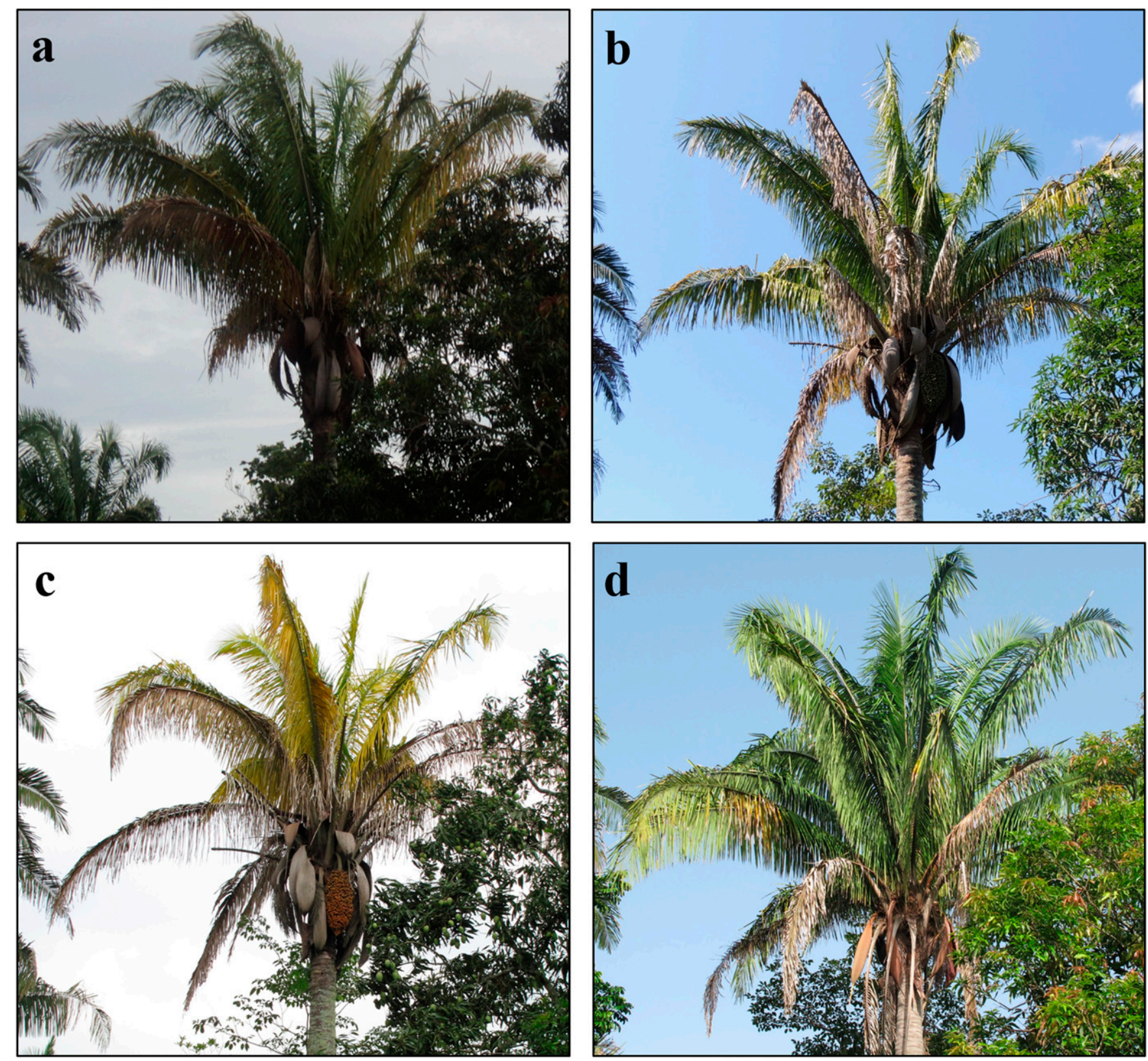

Fig. 2. Attalea butyracea showed only a slow decline over 49 months: a, yellowing of older leaves, July 2014; b, continuous yellowing in intermediate leaflets, December 2014; c, yellowing on all leaves, June 2015; and d, foliage recovery and death of inflorescence, July 2018. 
Sequence analysis. Sequence editing and assembly were carried out using the BioEdit 7.2.5 software (Hall 1999). The sequences obtained in this study were compared with those from known phytoplasmas using the Basic Local Alignment Search Tool (BLAST) system of the National Center for Biotechnology Information (https:// www.ncbi.nlm.nih.gov/). The sequences obtained were aligned using the ClustalX 2.1 software (Thompson et al. 1997). A phylogenetic tree was constructed with the phytoplasma sequences using Molecular Evolutionary Genetics Analysis (MEGA) 7.0.18 software (Kumar et al. 2016) and the neighbor-joining method, and it was evaluated with 2,000 replicates for the bootstrap analysis to estimate the stability of the inferred subclades. The 16S rRNA gene sequence from Bacillus subtilis (GenBank no. AJ544538) was used as an outgroup for the tree root.

In silico RFLP. Partial sequences from the 16S rRNA gene corresponding to the R16F2n/R2 fragment (Lee et al. 1995) were analyzed by RFLP in silico using the $i$ PhyClassifier tool.

\section{Results}

Phytoplasma detection in palms. All the samples from the 29 palms showing LY within rural and urban environments in Tabasco produced positive results for phytoplasma detection by nested PCR, whereas no detection was observed for the 13 asymptomatic palms analyzed (Table 1).

Symptomatology. The symptoms manifested by the PCR-positive palms varied depending on the species. In the rural environment with large-scale commercial activity in Pailebot, seven C. nucifera palms were found with typical LY symptoms, showing fruit drop, necrotic inflorescences, and yellowing of basal leaves. In a rural environment in the Miahuatlán community in Cunduacán used for family farming activities and as ornamentals, different palm species were found with LY-type symptoms. These included six $C$. nucifera palms showing LY symptoms as described above; four symptomatic A. merrillii palms showing necrotic inflorescences, brown leaves with collapsed but persistent petioles (whereas younger leaves were green and vertical), and an A. butyracea palm with leaf yellowing symptoms and complete fruit drop. Finally, eight $A$. merrillii palms in a city garden in the urban environment and another three A. merrillii palms in a Cárdenas housing unit showed the same symptoms as described above for $A$. merrillii palms in Cunduacán.

All $C$. nucifera and A. merrillii palms that were symptomatic and positive for phytoplasma presence in nested-PCR detection died during the study, whereas the positive A. butyracea palm showed only a slow decline over 49 months and has not died yet (Fig. 2).

In silico RFLP analysis and phytoplasma identification. The ribosomal DNA was sequenced from 20 out of the 29 samples from positive palms, and 16 sequences could be obtained (GenBank accession nos. MG881770 to MG881785). These sequences were subjected to virtual RFLP analysis of the $R 16 \mathrm{~F} 2 \mathrm{n} / \mathrm{R} 2$ region in the phytoplasma ribosomal gene, and the results showed that phytoplasmas enclosed in three different subgroups were present in the samples: 16SrIV-A, -B, and -D, with profiles identical to phytoplasmas of LY (GenBank no. U18747), Yucatan coconut lethal decline (GenBank no. U18753), and Sabal palmetto decline (GenBank no. HQ613895), respectively (Fig. 3).

The virtual RFLP patterns obtained with $A l u$ I digestion clearly differentiated 16SrIV-B and 16SrIV-D subgroups between themselves, whereas those of 16SrIV-A and 16SrIV-C had the same pattern with $A l u \mathrm{I}$ (Fig. 3) but were different with $\mathrm{Mse}$ I from the patterns of 16SrIV-A and 16SrIV-C (Fig. 3).

Phylogenetic analysis. The phylogenetic analysis on the 16SrRNA gene (Fig. 4) confirmed that all phytoplasmas from this study clustered within phytoplasmas in the 16SrIV clade and were separated into three subclades, corresponding to three ribosomal subgroups. The 16SrIV-A sequences were in the same subclade as the sequences of the $S$. mexicana (GenBank no. GU473589, Yucatán) and C. nucifera (GenBank no. AF498307, Jamaica) phytoplasmas. This phytoplasma subgroup was detected in diseased monocultures of $C$. nucifera palms within the agricultural area and family gardens located in the farming area. The $16 \mathrm{SrIV}-\mathrm{D}$ sequences from $A$. merrillii, $A$. butyracea, and $C$. nucifera were in the same subclade as Texas Phoenix decline (GenBank no. AF434989). These plants were used for farming purposes and as ornamentals in Miahuatlán, Cunduacán, and in the case of $A$. merrillii they were located within an urban area in the Cárdenas housing unit. The strains of the third phytoplasma subgroup, $16 \mathrm{SrIV}-\mathrm{B}$ in A. merrillii palms, clustered in the same subclade as Yucatan coconut lethal decline (GenBank nos. U18753 and AF500334). These plants were found in the central gardens at the Academic Division of Biological Sciences, Juarez Autonomous University of Tabasco.

\section{Discussion}

Phytoplasmas in the 16SrIV group are associated with lethal diseases of the coconut palm with high economic importance, as well as other ornamental palm species of commercial value, in North and Central America and the Caribbean Islands. The phytoplasmas in the 16SrIV subgroups have been associated with LY and LYtype diseases with symptoms similar to those of LY, including early fruit drop, inflorescence necrosis, leaf discoloration, and decline (Myrie et al. 2014). In the present study, three 16SrIV phytoplasma subgroups are reported: $16 \mathrm{SrIV}$-A detected in C. nucifera, $16 \mathrm{SrIV}-\mathrm{B}$ in A. merrillii, and 16SrIV-D in C. nucifera, A. merrillii, and A. butyracea. All these cases were detected in Tabasco State in Mexico.

The subgroup 16SrIV-A of phytoplasmas is associated with LY in C. nucifera and is the prevalent phytoplasma subgroup detected so far in several countries in the Caribbean region, including Mexico, with several reports confirming the presence of 16SrIV-A phytoplasmas in the states of Quintana Roo, Campeche, and Yucatán (Harrison et al. 2002b; Oropeza et al. 2011; Vázquez-Euán et al. 2011). The occurrence of $16 \mathrm{SrIV}$-A phytoplasmas has also been described in other palms, mostly used for ornamental purposes: for example, A. merrillii, Phoenix canariensis $\mathrm{H}$. Wildpret, and $P$. dactylifera $\mathrm{L}$. in Florida (Tymon et al. 1998) and Acrocomia mexicana Karw. ex Mart., Coccothrinax readii H.J. Quero, $S$. mexicana, T. radiata, and Roystonea regia (Kunth) O.F. Cook in Yucatán (Cordova et al. 2017; Narvaez et al. 2006; Vázquez-Euán et al. 2011). The current finding of this subgroup in $C$. nucifera in Tabasco extends the knowledge of its distribution in Mexico, suggesting that this subgroup is certainly the most widely distributed in Mexico and the Americas. This can be

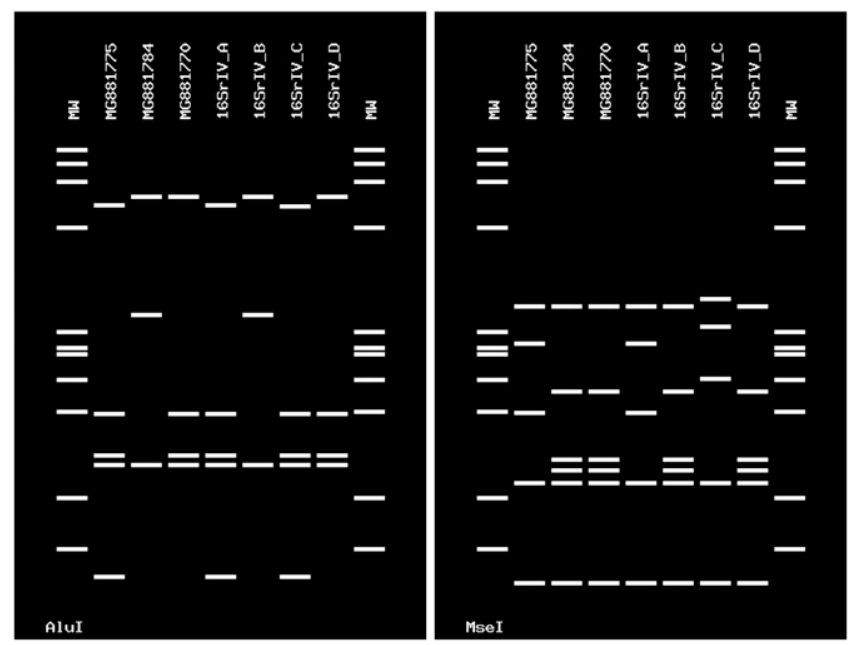

Fig. 3. Distinctive restriction fragment length polymorphism patterns obtained with iPhyClassifier from in silico digestion of the 16S rRNA gene (Zhao et al. 2009b) to determine the subgroup in the 16SrlV group. GenBank accession numbers of reference sequences used were as follows: 16SrIV-A (AF498307), 16SrIV-B (AF500334), 16SrIV-C (X80117), and 16SrIV-D (AF237615). The separation of the 16 SrlV-B and $-D$ subgroups is achieved by comparing the Alul profiles. The separation of $16 \mathrm{SrIV}-\mathrm{A}$ and $-\mathrm{C}$ is obtained by comparing the Msel band patterns. Restriction fragment polymorphisms are shown on a virtual $3 \%$ agarose gel. Lanes labeled MW represent Haelll-digested phage $\Phi$ X174 DNA. 
attributed to the ubiquitous distribution of the highly susceptible Atlantic Tall variety.

The 16SrIV-B phytoplasmas detected in A. merrillii palms were originally found in Tabasco in a $C$. nucifera palm showing atypical LY symptoms (Tymon et al. 1998). Subsequently, Harrison et al. (2002b) reported their presence in $C$. nucifera on the Pacific Coast in Mexico in Guerrero and Oaxaca. Later, a phytoplasma of the same subgroup was detected in Honduras in declining Acrocomia aculeata (Jacq.) Lodd. et al. ex Mart. palms (Roca et al. 2006). Other phytoplasma subgroups have been reported in A. merrillii. Recently, Cordova et al. (2017) reported 16SrIV-A and 16SrIV-D phytoplasmas occurring separately in different individuals of $A$. merrillii with LY

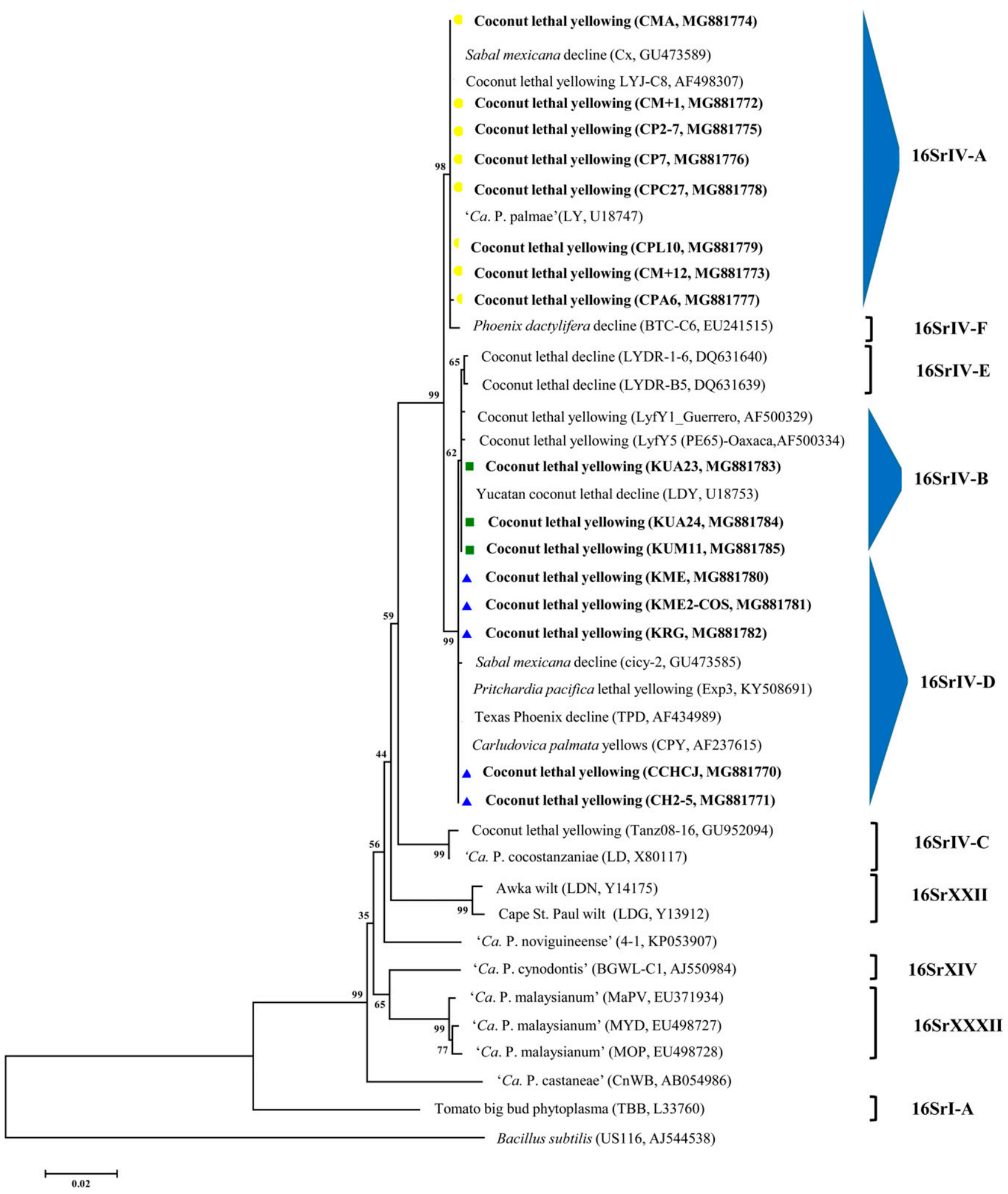

Fig. 4. Phylogenetic tree derived from selected phytoplasma $16 \mathrm{~S}$ rRNA gene sequences. The tree was constructed using the neighbor-joining method using the Tajima-Nei substitution model. Bacillus subtilis (GenBank no. AJ544538) was used as an outgroup to root the tree. The phytoplasma strain sequences obtained in this study are bolded and are grouped as indicated by circles, squares, and triangles. The branch length represents the distance between the sequences. The bootstrap values for 2,000 replicates are shown on the branches. The GenBank accession number for each sequence is indicated in parentheses followed by the phytoplasma subgroup. 
symptoms in urban landscapes in Mérida in Yucatán city. Therefore, this is the first report of the occurrence of a 16SrIV-B subgroup in $A$. merrillii. This phytoplasma subgroup seems, therefore, to have a wide geographical distribution, infecting several palm species growing in various ecological conditions.

Another phytoplasma that was also detected in the present study is 16SrIV-D. It was found in C. nucifera, A. merrillii, and A. butyracea palms that were planted for different purposes, in rural areas in Miahuatlán in Tabasco. This phytoplasma subgroup had already been reported in Mexico, in C. nucifera palms in the states of Guerrero and Oaxaca on the Pacific Coast of Mexico (Harrison et al. 2002b) and in A. merrillii, $P$. sargentii, S. mexicana, T. radiata, and Pritchardia pacifica Seem. \& H. Wendl. in urban landscapes of Yucatán (Cordova et al. 2017; Narváez et al. 2017; Vázquez-Euán et al. 2011), and also in a nonpalm species, Carludovica palmata Ruiz \& Pav., in Campeche State (Cordova et al. 2000).

16SrIV-D has also been detected in different states and territories of the United States. In Florida, it has been found in Butiagrus nabonnandii (Prosch.) Vorster, $P$. canariensis, P. roebelenii O'Brien, $P$. dactylifera, $P$. sylvestris (L.) Roxb., $P$. reclinata Jacq., $S$. palmetto (Walter) Lodd. ex Schult. \& Schult. f., Syagrus romanzoffiana (Cham.) Glassman, $P$. sylvestris $\times P$. dactylifera Chab. hybrid, and $P$. sylvestris $\times P$. canariensis hybrid Chab. (Bahder et al. 2018a, 2018b; Harrison et al. 2008); in Louisiana, it was found in Trachycarpus fortunei (Hook.) H. Wendl. (Singh and Ferguson 2017); in Texas, it was found in different $P$. canariensis and $P$. dactylifera species affected with TPPD (Harrison et al. 2002a; Ntushelo et al. 2013); in Puerto Rico, this subgroup was reported to affect the palms of the landscape and tourism industry, where the affected species were Roystonea sp. O.F. Cook, Carpentaria acuminata (H. Wendl. \& Drude) Becc., and Caryota mitis Lour. (Rodrigues et al. 2010).

The three species of host palms reported in this study coexist in Miahuatlán with at least two subgroups of phytoplasmas that could have favored the occurrence of mixed infections as reported by Harrison et al. (2008), in P. dactylifera with 16SrIV-A and 16SrIV-F; however, in this study, no mixed infection was detected.

In conclusion, the present report is the first detecting the presence of phytoplasmas 16SrIV-A, 16SrIV-B, 16SrIV-D in palm plants in Tabasco, and also the first report of 16SrIV-B in A. merrillii and 16SrIV-D in A. butyracea. These results extend the knowledge of the host diversity of these phytoplasmas and widen their geographic distribution. There is a need for continuing research efforts on the diversity of phytoplasmas in different host plant species, and to study their geographic distribution together with the identification of other insect vectors.

\section{Literature Cited}

Alvarez, E., Mejía, J. F., Contaldo, N., Paltrinieri, S., Duduk, B., and Bertaccini, A. 2014. 'Candidatus Phytoplasma asteris' strains associated with oil palm lethal wilt in Colombia. Plant Dis. 98:311-318.

Bahder, B. W., Helmick, E. E., Chakrabarti, S., Osorio, S., Soto, N., Chouvenc, T., and Harrison, N. A. 2018a. Disease progression of a lethal decline caused by the 16SrIV-D phytoplasma in Florida palms. Plant Pathol. 67:1821-1828.

Bahder, B. W., Helmick, E. E., Mou, D.-F., Harrison, N. A., and Davis, R. 2018b. Digital PCR technology for detection of palm-infecting phytoplasmas belonging to group 16SrIV that occur in Florida. Plant Dis. 102:1008-1014.

Bertaccini, A. 2007. Phytoplasmas: Diversity, taxonomy, and epidemiology. Front. Biosci. 12:673-689.

Bertaccini, A., Duduk, B., Paltrinieri, S., and Contaldo, N. 2014. Phytoplasmas and phytoplasma diseases: A severe threat to agriculture. Am. J. Plant Sci. 5: 1763-1788.

Cordova, I., Oropeza, C., Almeyda, H., and Harrison, N. A. 2000. First report of a phytoplasma-associated leaf yellowing syndrome of Palma Jipi plants in Southern Mexico. Plant Dis. 84:807.

Cordova, I., Mota Narváez, L. M., Puch Hau, C., Oropeza, C., and Sáenz, L. 2017. Detection and identification of lethal yellowing phytoplasma 16SrIV-A and D associated with Adonidia merrillii palms in Mexico. Australas. Plant Pathol. 46: 389-396.

Deng, S., and Hiruki, C. 1991. Amplification of 16S rRNA genes from culturable and non-culturable mollicutes. J. Microbiol. Methods 14:53-61.

Doyle, J. J., and Doyle, J. I. 1990. Isolation of DNA from fresh plant tissue. Focus 12:13-15.

Gasparich, G. E. 2010. Spiroplasmas and phytoplasmas: Microbes associated with plant hosts. Biologicals 38:193-203.
Gundersen, D. E., and Lee, I.-M. 1996. Ultrasensitive detection of phytoplasmas by nested-PCR assays using two universal primer pairs. Phytopathol. Mediterr. 35:144-151

Hall, T. A. 1999. BioEdit: A user-friendly biological sequence alignment editor and analysis program for Windows 95/98/NT. Nucleic Acids Symp. Ser. 41: 95-98.

Harrison, N., Cordova, I., Richardson, P., and Dibonito, R. 1999. Detection and diagnosis of lethal yellowing. Pages 183-196 in: Current Advances in Coconut Biotechnology. C. Oropeza, J. L. Verdeil, G. R. Ashburner, R. Cardeña, and J. M. Santamaría, eds. Springer, Dordrecht, the Netherlands.

Harrison, N., Helmick, E., and Elliott, M. 2008. Lethal yellowing-type diseases of palms associated with phytoplasmas newly identified in Florida, USA. Ann. Appl. Biol. 153:85-94.

Harrison, N. A., Davis, R. E., Oropeza, C., Helmick, E. E., Narvaez, M., EdenGreen, S., Dollet, M., and Dickinson, M. 2014. 'Candidatus Phytoplasma palmicola', associated with a lethal yellowing-type disease of coconut (Cocos nucifera L.) in Mozambique. Int. J. Syst. Evol. Microbiol. 64:1890-1899.

Harrison, N. A., Myrie, W., Jones, P., Carpio, M. L., Castillo, M., Doyle, M. M., and Oropeza, C. 2002. 16S rRNA interoperon sequence heterogeneity distinguishes strain populations of palm lethal yellowing phytoplasma in the Caribbean region. Ann. Appl. Biol. 141:183-193.

Harrison, N. A., Narvaez, M., Almeyda, H., Cordova, I., Carpio, M. L., and Oropeza, C. 2002b. First report of group 16SrIV phytoplasmas infecting coconut palms with leaf yellowing symptoms on the Pacific coast of Mexico. Plant Pathol. 51:808.

Harrison, N. A., Womack, M., and Carpio, M. L. 2002a. Detection and characterization of a lethal yellowing (16SrIV) group phytoplasma in Canary Island date palms affected by lethal decline in Texas. Plant Dis. 86:676-681.

Howard, F., Norris, R., and Thomas, D. 1983. Evidence of transmission of palm lethal yellowing agent by a planthopper, Myndus crudus (Homoptera, Cixiidae). Trop. Agric. 60:168-171.

Kumar, S., Stecher, G., and Tamura, K. 2016. MEGA7: Molecular Evolutionary Genetics Analysis version 7.0 for bigger datasets. Mol. Biol. Evol. 33: $1870-1874$

Lee, I.-M., Bertaccini, A., Vibio, M., and Gundersen, D. E. 1995. Detection of multiple phytoplasmas in perennial fruit trees with decline symptoms in Italy. Phytopathology 85:728-735.

Lee, I.-M., Davis, R. E., and Gundersen, D. E. 2000. Phytoplasma: Phytopathogenic mollicutes. Annu. Rev. Microbiol. 54:221-255.

Lee, I.-M., Gundersen, D. E., and Bertaccini, A. 1998a. Phytoplasma: Ecology and genomic diversity. Phytopathology 88:1359-1366.

Lee, I.-M., Gundersen-Rindal, D. E., Davis, R. E., and Bartoszyk, I. M. 1998b. Revised classification scheme of phytoplasmas based on RFLP analyses of $16 \mathrm{~S}$ rRNA and ribosomal protein gene sequences. Int. J. Syst. Evol. Microbiol. 48:1153-1169.

Lee, I.-M., Hammond, R. W., Davis, R. E., and Gundersen, D. E. 1993. Universal amplification and analysis of pathogen 16S rDNA for classification and identification of mycoplasmalike organisms. Phytopathology 83:834-842.

Manimekalai, R., Nair, S., and Soumya, V. P. 2014. Evidence of 16SrXI group phytoplasma DNA in embryos of root wilt diseased coconut palms. Australas. Plant Pathol. 43:93-96.

Martinez, R. T., Narvaez, M., Fabre, S., Harrison, N., Oropeza, C., Dollet, M., and Hichez, E. 2008. Coconut lethal yellowing on the southern coast of the Dominican Republic is associated with a new 16SrIV group phytoplasma. Plant Pathol. 57:366.

Miyazaki, A., Shigaki, T., Koinuma, H., Iwabuchi, N., Rauka, G. B., Kembu, A., Saul, J., Watanabe, K., Nijo, T., Maejima, K., Yamaji, Y., and Namba, S. 2018 'Candidatus Phytoplasma noviguineense', a novel taxon associated with Bogia coconut syndrome and banana wilt disease on the island of New Guinea. Int. J. Syst. Evol. Microbiol. 68:170-175.

Myrie, W., Harrison, N., Douglas, L., Helmick, E., Gore-Francis, J., Oropeza, C., and McLaughlin, W. 2014. First report of lethal yellowing disease associated with subgroup 16SrIV-A phytoplasmas in Antigua, West Indies. New Dis. Rep. 29:12.

Naderali, N., Nejat, N., Vadamalai, G., Davis, R. E., Wei, W., Harrison, N. A., Kong, L., Kadir, J., Tan, Y.-H., and Zhao, Y. 2017. 'Candidatus Phytoplasma wodyetiae', a new taxon associated with yellow decline disease of foxtail palm (Wodyetia bifurcata) in Malaysia. Int. J. Syst. Evol Microbiol. 67:3765-3772.

Narvaez, M., Cordova, I., Orellana, R., Harrison, N. A., and Oropeza, C. 2006 First report of a lethal yellowing phytoplasma in Thrinax radiata and Coccothrinax readii palms in the Yucatan Peninsula of Mexico. Plant Pathol. 55:292.

Narváez, M., Ortíz, E., Silverio, C., Santamaría, J. M., Espadas, F., and Oropeza, C. 2017. Changes observed in Pritchardia pacifica palms affected by a lethal yellowing-type disease in Mexico. Afr. J. Biotechnol. $16: 2331-2340$

Nejat, N., Sijam, K., Abdullah, S. N. A., Vadamalai, G., and Dickinson, M. 2009 First report of a $16 \mathrm{SrXIV}$, 'Candidatus Phytoplasma cynodontis' group phytoplasma associated with coconut yellow decline in Malaysia. Plant Pathol. 58:389.

Nejat, N., Vadamalai, G., Davis, R. E., Harrison, N. A., Sijam, K., Dickinson, M., Abdullah, S. N. A., and Zhao, Y. 2013. 'Candidatus Phytoplasma 
malaysianum', a novel taxon associated with virescence and phyllody of Madagascar periwinkle (Catharanthus roseus). Int. J. Syst. Evol. Microbiol. 63:540-548.

Ntushelo, K., Harrison, N. A., and Elliott, M. L. 2013. Palm phytoplasmas in the Caribbean Basin. Palms 57:93-100.

Oropeza, C., Cordova, I., Chumba, A., Narvaez, M., Saenz, L., Ashburner, R., and Harrison, N. 2011. Phytoplasma distribution in coconut palms affected by lethal yellowing disease. Ann. Appl. Biol. 159:109-117.

Roca, M. M., Castillo, M. G., Harrison, N. A., and Oropeza, C. 2006. First report of a 16SrIV group phytoplasma associated with declining coyol palms in Honduras. Plant Dis. 90:526.

Rodrigues, J. V., Vitoreli, A. M., and Ramirez, A. L. 2010. Association of a phytoplasma with dieback in palms in Puerto Rico confirmed by nested-PCR assays. Phytopathology 100:S110.

Santos-Cervantes, M. E., Chavez-Medina, J. A., Mendez-Lozano, J., and LeyvaLopez, N. E. 2008. Detection and molecular characterization of two little leaf phytoplasma strains associated with pepper and tomato diseases in Guanajuato and Sinaloa, Mexico. Plant Dis. 92:1007-1011.

Schneider, B., Ahrens, U., Kirkpatrick, B. C., and Seemüller, E. 1993. Classification of plant-pathogenic mycoplasma-like organisms using restriction-site analysis of PCR-amplified 16S rDNA. Microbiology 139:519-527.

Schneider, B., Seemüller, E., Smart, C. D., and Kirkpatrick, B. C. 1995. Phylogenetic classification of plant pathogenic mycoplasma-like organisms or phytoplasmas. Pages 369-380 in: Molecular and Diagnostic Procedures in Mycoplasmology. Vol. I, Molecular Characterization. R. Razin and J. G. Tully, eds. Academic Press, San Diego, CA.
Singh, R., and Ferguson, M. H. 2017. First report of a 'Candidatus Phytoplasma palmae'-related subgroup 16SrIV-D phytoplasma on Trachycarpus fortunei. Australas. Plant Dis. Notes 12:59.

Thompson, J. D., Gibson, T. J., Plewniak, F., Jeanmougin, F., and Higgins, D. G. 1997. The CLUSTAL_X Windows Interface: Flexible strategies for multiple sequence alignment aided by quality analysis tools. Nucleic Acids Res. 25:4876-4882.

Tymon, A. M., Jones, P., and Harrison, N. A. 1998. Phylogenetic relationships of coconut phytoplasmas and the development of specific oligonucleotide PCR primers. Ann. Appl. Biol. 132:437-452.

Vázquez-Euán, R., Harrison, N., Narvaez, M., and Oropeza, C. 2011. Occurrence of a 16SrIV group phytoplasma not previously associated with palm species in Yucatan, Mexico. Plant Dis. 95:256-262.

Wei, W., Davis, R. E., Lee, I.-M., and Zhao, Y. 2007. Computer-simulated RFLP analysis of $16 \mathrm{~S}$ rRNA genes: Identification of ten new phytoplasma groups. Int. J. Syst. Evol. Microbiol. 57:1855-1867.

Zhao, Y., Sun, Q., Wei, W., Davis, R. E., Wu, W., and Liu, Q. 2009a. 'Candidatus Phytoplasma tamaricis', a novel taxon discovered in witches-broom-diseased salt cedar (Tamarix chinensis Lour.). Int. J. Syst. Evol. Microbiol. 59:2496-2504.

Zhao, Y., Wei, W., Lee, I. M., Shao, J., Suo, X., and Davis, R. E. 2009b. Construction of an interactive online phytoplasma classification tool, $i$ PhyClassifier, and its application in analysis of the peach X-disease phytoplasma group (16SrIII). Int. J. Syst. Evol. Microbiol. 59:2582-2593.

Zhao, Y., Wei, W., Lee, I.-M., Shao, J., Suo, X., and Davis, R. E. 2013. The $i$ PhyClassifier, an interactive online tool for phytoplasma classification and taxonomic assignment. Pages 329-338 in: Phytoplasma: Methods and Protocols. M. Dickinson and J. Hodgetts, eds. Humana Press, Totowa, NJ. 